\title{
PENGARUH QUALITY OF WORK LIFE ( $Q W L)$ DAN MOTIVASI TERHADAP KINERJA PEGAWAI KECAMATAN DI KABUPATEN KULONPROGO D.I YOGYAKARTA
}

\author{
Susilo Ari Wibowo ${ }^{1}$ \\ ${ }^{1}$ Pemerintah Daerah Kabupaten Kulon Progo \\ swibowo48@yahoo.com
}

\begin{abstract}
The purpose of this research is to look at the effect Quality of Work Life, Need for Achievement, Need for Affiliation, dan Need for Power, on the performance of the employees subdistrict of Kulon Progo regency Special Province of Yogyakarta.

The data collection was conducted by distributing questionnaires addressed to the 267 employees, to obtain an answer for each item of respondents' perception of the research variable statement. Of the tota questionnaires distributed, 214 questionnaires were returned and readily processed. The data analysis method used was multiple regression analysis to examine the effect Quality of Work Life, Need for Achievement, Need for Affiliation, dan Need for Power, on the performance.

The test conducted partially showed that Quality of Work Life, Need for Achievement, Need for Affiliation have a significant positive impact on the performance of the employees subdistrict of Kulon Progo regency. On the other hand, Need for Power does not affect the performance of the employees subdistrict of Kulon Progo regency. While the test conducted simultaneously showed that Quality of Work Life, Need for Achievement, Need for Affiliation, dan Need for Power have a significant positive impact on the performance of the employees subdistrict of Kulon Progo regency.
\end{abstract}

Keywords: Quality of Work Life, Need for Achievement, Need for Affiliation, Need for Power, and Performance.

(C) 2017 JBTI. All rights reserved

Article history : received 17 Jul 2016; revised 18 Ags 2016; accepted 20 Des 2016

\section{PENDAHULUAN}

Masalah yang menjadi bahasan pada penulisan ini adalah bagaimana organisasi mampu mengelola serta dapat memanfaatkan sumber daya manusia secara optimal sehingga bermanfaat untuk menunjang upaya organisasi dalam mencapai tujuan secara berkelanjutan. Konsekwensi pemberian kewenangan yang luas kepada Pemerintah Daerah dalam Undang-Undang No. 32 Tahun 2004, adalah :

a. Pemerintah Daerah harus mampu membiayai semua kegiatan pemerintah dan pembangunan yang menjadi kewenangannya,

b. harus memiliki kemampuan untuk menggali sumber-sumber keuangan sendiri. Pengelolaan dan penggunaan keuangan sendiri tersebut harus cukup memadai untuk pembiayaan enyelenggaraan pemerintah dan pembangunan daerah. 
Kondisi dan informasi SKPD Kecamatan di Kabupaten Kulon Progo sesuai hasil survei Indek Kepuasan Masyarakat (IKM) dalam hal urusan pelayanan dari tahun 2013-2015, kondisi Satuan Kerja Daerah Kecamatan di Kabupaten Kulon Progo secara umum mengalami penurunan dan Evaluasi LAKIP (Laporan Akuntabilitas Kinerja Instansi Pemerintah), Tahun 2014, dengan rekomendasi agar menyempurnakan evaluasi internal program/kegiatan secara berkala dan menyempurnakan capaian sasaran/kinerja organisasi Untuk itulah kita perlu mengetahui kualitas kehidupan kerja yang ada dalam organisasi, dan juga yang perlu dipahami bahwa setiap individu mempunyai kebutuhan yang berbeda-beda dimana kebutuhan individu tersebut dapat mempengaruhi kinerja.

Dengan latar belakang masalah tersebut di atas, maka penelitian ini akan menganalisis "Pengaruh Quality of Work Life dan Motivasi (Need for Achievement, Need for Affiliation, Need for Power, ) terhadap Kinerja Pegawai Kecamatan di Kabupaten Kulon Progo".

\section{KAJIAN TEORI}

\section{A. Quality of Work Life}

Konsep kualitas kehidupan kerja mengungkapkan pentingnya penghargaan terhadap manusia dalam lingkungan kerjanya. Dengan demikian peran penting dari kualitas kehidupan kerja adalah mengubah iklim organisasi agar secara teknis dan manusiawi membawa kepada kualitas kehidupan kerja yang lebih baik (Luthans, 1995). Sebuah kualitas kehidupan kerja yang baik adalah hal yang sangat penting dan mendasar di dalam perusahaan untuk menarik dan mempertahankan para karyawan atau pekerjanya. Sehingga banyak manajer perusahaan yang berusaha untuk mengurangi ketidakpuasan kualitas kehidupan kerja para karyawannya (Saraji \& Dargahi, 2006). Instrumen Quality of Work Life terdiri atas beberapa dimensi yang kembangkan dengan pendekatan validitas isi, antara lain:

1. Dimensi Partisipasi, berhubungan dengan keterbukaan penyampaian gagasan dan keterlibatan pegawai dalam proses pembuatan kebijakan organisasi.

2. Dimensi Restrukturisasi Kerja, hal ini berhubungan dengan kesempatan pegawai dalam mengembangkan diri dalam meningkatkan kemampuan dalam penyelesaian pekerjaan dengan program pelatiahan, karir dan ketersediaan pendukung buku referensi.

3. Dimensi Sistem Imbalan, berhubungan dengan kejelasan dan keadilan dalam hal pemberian tambahan kompensasi, dan termasuk fasilitas kesehatan.

4. Dimensi Lingkungan Kerja, berhubungan dengan kenyamanan bekerja dalam organisasi , jaminan keselamatan bekerja, dan kondisi ruang bekerja pegawai yang nyaman.

\section{B. Motivasi.} yaitu:

Menurut Mc Clelland (Rivai, 2004) menyebutkan bahwa ada tiga tipe kebutuhan Motivasi,

1. Need for Power, yaitu manusia yang mempunyai keinginan berkuasa tinggi mempunyai keinginan yang besar untuk menanamkan pengaruhnya dan mengendalikan orang lain,

2. Need for Affiliation, yaitu manusia mempunyai kebutuhan afiliasi yang tinggi, umumnya senang sosialisasi, senang dicintai dan tidak menyukai kesendirian, dan terakhir.

3. Need for Achievement, yaitu manusia mempunyai kebutuhan berprestasi tinggi, mempunyai keinginan tinggi untuk sukses. 


\section{Kinerja}

Kinerja merupakan dasar dalam produktivitas organisasi yang akan berkontribusi dalam mencapai tujuan organisasi. Kinerja merupakan perilaku nyata yang ditampilkan setiap orang sebagai prestasi kerja yang dihasilkan oleh pegawai sesuai dengan perannya dalam organisasi, hal ini menjadi harapan bagi semua organisasi yang memiliki karyawan, dengan harapan kinerja karyawan inilah yang mampu meningktakan kinerja dalam upaya organisasi mencapai tujuan. Veithzal R. (2005) mendefinisikan kinerja adalah hasil atau tingkat keberhasilan seseorang, secara keseluruhan selama periode tertentu di dalam melaksanakan tugas dibandingkan dengan berbagai kemungkinan, seperti standar hasil kerja, target atau sasaran atau kriteria yang telah ditentukan terlebih dahulu dan terjemahan dari kata performance. As'ad (1991), kinerja merupakan kesuksesan seseorang dalam dalam melaksanakan suatu pekerjaan.Kinerja pada dasarnya merupakan hasil kerja seorang karyawan selama periode tertentu dan berhasil tidaknya kinerja karyawan dipengaruhi oleh tingkat kinerja karyawan secara individu maupun kelompok. Menurut Gibson (2010), Kinerja individu adalah dasar kinerja organisasi, karena organisasi tergantung pada kinerja individu. Menurut Mangkunegara (2001), Kinerja adalah hasil kerja secara kuwalitas dan kuantitas yang dicapai oleh seorang pegawai dalam melaksanakan tugas sesuai dengan tanggung jawab yang diberikan kepadanya.

\section{Kerangka Pemikiran}

Untuk mengetahui seberapa besar pengaruh hubungan variable independen Qualiity of Work Life (X1) dan Motivasi Need for Achievement (X2), Need for Affiliation (X3), Need for Power ( X4 ) terhadap variable independen Kinerja pegawai (Y), dengan model alur pikir sebagai berikut

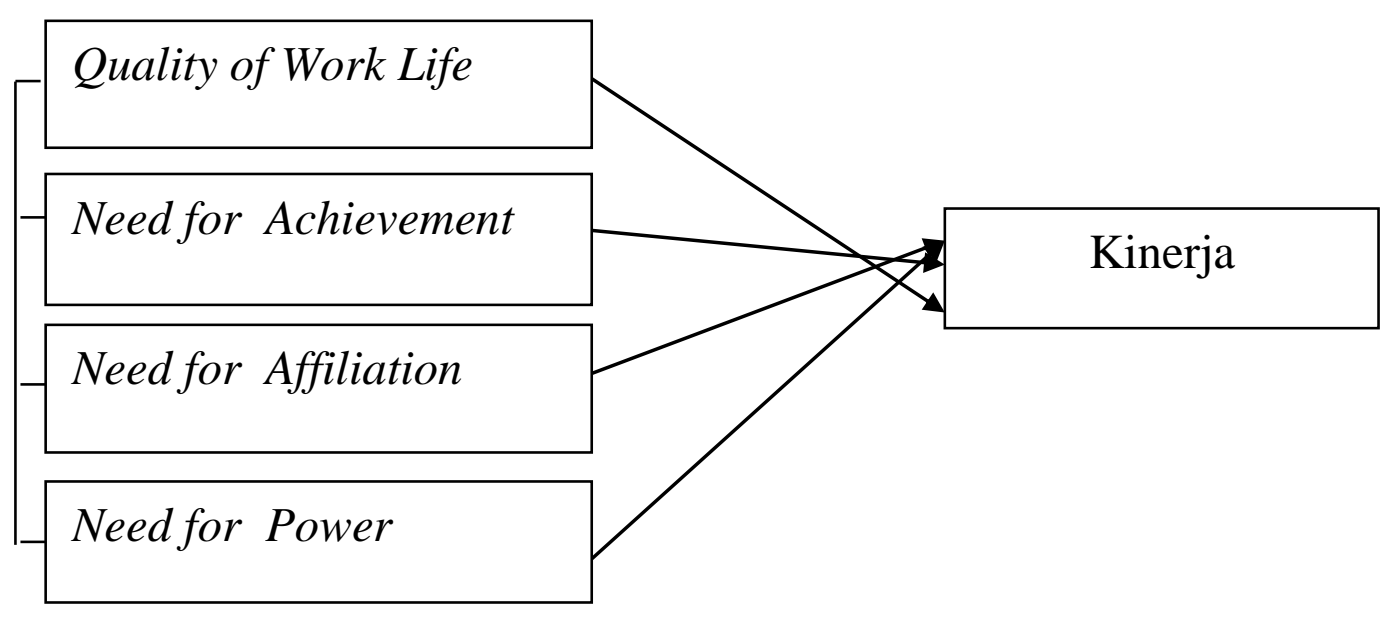

Gambar. B.4.1 Kerangka Pemikiran Teoritis

\section{Hipotesis}

Hipotesis dalam penelitian ini, dirumuskan sebagai berikut :

H1 : Quality of Work Life yang terdiri dari dimensi Partisipasi kerja, Restrukturisasi kerja, Sistem imbalan, Lingkungan kerja, dan Motivasi (Need for Achievement, Need for Affiliation, Need for Power) secara bersama berpengaruh positif signifikan terhadap Kinerja pegawai kecamatan di Kabupaten Kulon Progo.

H2 : Quality of Work Life berpengaruh positif signifikan terhadap Kinerja pegawai kecamatan di Kabupaten Kulon Progo.

H3 : Need for Achievement (Motivasi Kebutuhan berprestasi), berpengaruh positif signifikan terhadap Kinerja pegawai kecamatan di Kabupaten Kulon Progo. 
H4 : Need for Affiliation (Motivasi Kebutuhan berafiliasi), berpengaruh positif signifikan terhadap Kinerja pegawai kecamatan di Kabupaten Kulon Progo.

H5 : Need for Power (Motivasi Kebutuhan kekuasaan), berpengaruh positif signifikan terhadap Kinerja pegawai kecamatan di Kabupaten Kulon Progo.

\section{METODE PENELITIAN}

\section{A. Obyek dan Subyek Penelitian}

Penelitian ini adalah penelitian populasi. Populasi merupakan keseluruhan kelompok, peristiwa atau segala sesuatu yang menarik bagi peneliti untuk diteliti (Tjahjono, 2015)

Sebagai obyek adalah Satuan Kerja Perangkat Daerah kecamatan se-Kabupaten Kulon Progo dengan pegawai kecamatan di Kabupaten Kulon Progo sebagai subyek penelitian ini sebanyak 267 orang.

\section{B. Jenis Data}

Data yang digunakan dalam penelitian ini data kuantitatif, diperoleh melalui sumber data primer, dimana data mengacu pada informasi yang diperoleh dari tangan pertama oleh peneliti yang berkaitan dengan tujuan spesifik penelitian.

\section{Teknik Pengumpulan data}

Teknik Pengumpulan data dari populasi adalah metode angket yaitu dengan memberikan daftar pertanyaan atau quisioner kepada pegawai Kecamatan yang berada di wilayah Kabupaten Kulon Progo. Responden mengisi jawaban daftar pertanyaan dengan menggunakan Skala Likert. Teknik analisis yang digunakan adalah Analisis Regresi Berganda dengan menggunakan sarana uji statistik untuk mengetahui seberapa besar pengaruh hubungan antara variable $(\mathrm{X} 1),(X 2),(X 3)$, dan ( X4 ) terhadap variable independen (Y).

\section{Definisi Operasional Variabel Penelitian}

1) Quality of Wok Llife

Untuk variabel Quality of Work Llife, dalam penelitian ini, instrumen Quality of Work Life ada bebarapa dimensi yang kembangkan dengan pendekatan validitas isi. Beberapa dimensi tersebut antara lain :

a. Dimensi Partisipasi, diantaranya adalah :

Pimpinan selalu memperhatikan pendapat/ saran karyawan, atasan terbuka pada gagasangagasan yang disampaikan karyawan, dan karyawan sering dilibatkan dalam proses-proses pembuatan keputusan di kantor.

b. Dimensi Restrukturisasi Kerja, diantaranya adalah :

Pimpinan sering memberi kesempatan kepada karyawan untuk mengembangkan inisiatif dan kreatifitas dalam menyelesaikan pekerjaan, Karyawan diberi kesempatan memecahkan persoalan dalam bidang masing-masing, Kenaikan karir di kantor terkait dengan latar belakang pendidikan karyawan, Pimpinan memberi kesempatan karyawan mengembangkan diri melalui 
program-program pelatihan, Pimpinan selalu memperhatikan jenjang kepangkatan seluruh karyawan, tempat kerja menyediakan bahan bacaan dan referensi yang memadai bagi karyawan.

c. Dimensi Sistem Imbalan, diantaranya adalah :

Sistem imbalan yang diberikan perusahaan jelas dan adil kepada para karyawan, Perusahaan memberikan sejumlah tambahan berupa bonus dan insentif yang menarik, Perusahaan memberikan fasilits kesehatan yang memadai, Perusahaan memberikan fasilitas THR yang memadai.

d. Dimensi Lingkungan Kerja, diantaranya adalah :

Karyawan merasa nyaman bekerja di tempat kerja, Jaminan keselamatan ditempat kerja memadai, Jaminan kesehatan karyawan diperhatikan, fasilitasi dan penerangan di ruang kerja telah memberikan rasa nyaman.

\section{2) Motivasi}

Motivasi merupakan dorongan upaya dan keinginan yang di dalam diri manusia yang mengaktifkan, memberi daya serta mengarahkan perilakunya untuk melaksanakan tugas dan tanggung jawab dalam lingkup pekerjaan seseorang.

Mc Clelland menjelaskan bahwa prestasi kita dalam bekerja ditentukan oleh tiga kebutuhan yang ada dalam diri kita, yaitu kebutuhan untuk berprestasi, kebutuhan affiliasi dan kebutuhan kekuasaan. Pendapatnya berbasis pada riset menyatakan bahwa level perkembangan ekonomi bangsa berhubungan dengan level motivasi berprestasi manusianya, dengan penjelasan sebagai berikut :

a) Need for Achievement (kebutuhan berprestasi) memiliki tiga dimensi penting ( Kreitner \& Kinicky, 2004), yaitu: suka mengambil risiko yang moderat, dalam pandangan mereka, prestasi lebih disebabkan faktor mereka sendiri daripada faktor lain, memerlukan umpan balik yang cepat terkait keberhasilan dan kegagalan mereka.

b) Need for Affiliation (kebutuhan affiliasi) memiliki beberapa dimensi yaitu: lebih suka mempertahankan hubungan, lebih suka kerja kelompok, menginginkan pengakuan dan kasih saying.

c) Need for Power (kebutuhan kekuasaan) merefleksikan keinginan untuk: mempengaruhi, mementor, mengajarkan dan mendorong pencapaian prestasi.

\section{3) Kinerja}

Kinerja karyawan merupakan kesuksesan seseorang dalam dalam melaksanakan suatu pekerjaan. Kinerja pada dasarnya merupakan hasil kerja seorang karyawan selama periode tertentu dan berhasil tidaknya kinerja karyawan dipengaruhi oleh tingkat kinerja karyawan secara individu maupun kelompok. Kinerja diukur melalui lima indikator, antara lain :

a) Kualitas, yaitu hasil kegiatan yang dilakukan mendekati sempurna dalam artian menyesuaikan dengan beberapa cara ideal dari penampilan kegiatan dalam memenuhi tujuan yang diharapkan.

b) Kuantitas, yaitu jumlah atau target yang dihasilkan dinyatakan dalam istilah unit jumlah siklus aktivitas yang diselesaikan.

c) Ketepatan waktu, yaitu aktivitas yang diselesaikan pada waktu awal yang diinginkan dilihat dari sudut koordinasi dari hasil output sereta memaksimalkan waktu yang tersedia untuk aktivitas lain.

d) Komunikasi, yaitu hubungan atau interaksi dengan sesame rekan kerja dalam organisasi. 


\section{ANALISIS DATA DAN HASIL PENELITIAN}

\section{A. Hasil}

Hasil perhitungan uji validitas terhadap pertanyaan variabel Quality of Work Life dan Motivasi (Need for Achievement, , Need for Affiliation, Need for Power, dan kinerja menunjukkan bahwa seluruh pertanyan valid. Pertanyaan dinyatakan valid karena nilai korelasi lebih besar dari $r$ tabel atau tingkat signifikansi hasil output SPSS kurang dari 0,05 persen.

\section{Tabel .1}

Hasil Uji Validitas

\begin{tabular}{|l|r|r|r|r|r|}
\hline \multicolumn{1}{|c|}{ Variabel } & $\begin{array}{r}\text { Anti-image } \\
\text { Correlation }\end{array}$ & Cumulatif & Extraction & KMO & Bartletts \\
test & Sig \\
\hline QWL & 0,725 & & & & \\
Need for Achievement & 0,704 & & & & \\
Need for Afiliation & 0,668 & & & & \\
Need for Power & 0,657 & & & & \\
\hline Uji validitas & & 63,79 & 0,698 & 157,236 & 0,00 \\
\hline
\end{tabular}

Sumber: Data diolah

Nilai KMO sebesar 0,698 menandakan bahwa instrument valid karena sudah memenuhi batas 0,50. Korelasi inti image menghasilkan nilai yang cukup untuk masing-masing variabel yaitu 0,725 $\left(\mathrm{X}_{1}\right), 0,704\left(\mathrm{X}_{2}\right), 0,668\left(\mathrm{X}_{3}\right)$ dan 0,657( $\left.\mathrm{X}_{4}\right)$.Total Variance Explained menunjukkan bahwa keempat variabel yang digunakan, ekstraksi SPSS menjadi 1 faktor dengan kemampuan menjelaskan konstruk sebesar 63,79 persen.Component Matrix memperlihatkan bahwa seluruh variabel memiliki loading faktor yang besar yaitu di atas 0,50 . Hal ini menandakan bahwa variabel tersebut valid.

Sedangkan hasil uji reliabilitas ditunjukkan dalam table sebagai berikut

Tabel .2

Hasil Uji Reliabilitas

\begin{tabular}{|l|r|l|l|}
\hline \multicolumn{1}{|c|}{ Variabel } & Alpha Cronbach & Kriteria & \multicolumn{1}{|c|}{ Keterangan } \\
\hline QWL & 0,862 & & Reliabel \\
\cline { 1 - 2 } Need for Achievement & 0,603 & \multirow{2}{*}{$\begin{array}{l}\text { Alpha Cronbach }> \\
0,600 \text { maka } \\
\text { reliabel }\end{array}$} & Reliabel \\
\cline { 1 - 2 } Need for Afiliation & 0,600 & Reliabel \\
\cline { 1 - 2 } Need for Power & 0,620 & & Reliabel \\
\cline { 1 - 2 } Kinerja & 0,628 & & Reliabel \\
\hline
\end{tabular}

Sumber: data diolah 
Hasil pengolahan SPSS menunjukkan bahwa semua nilai Cronbach's Alpha tiap variabel di atas 0,600 artinya seluruh pertanyaan layak untuk digunakan.

Sebelum dilakukan pengolahan regresi, terlebih dahulu dilakukan beberapa uji yang menjadi syarat dalam analisis regresi.

1. Uji normalitas data

Pengujian normalitas digunakan untuk menguji apakah dalam sebuah model regresi variabel-variabelnya mempunyai distribusi normal atau tidak.Model yang baik adalah model dengan data normal atau mendekati normal. Terlihat dalam gambar 1 bahwa Normal P-P plot of regression Standardized Residual, terlihat bahwa titik titik menyebar disekitar garis diagonal, serta penyebarannya mengikuti arah garis diagonal (membentuk garis lurus ), maka dapat dikatakan bahwa data berdistribusi normal dan model regresi layak dipakai untuk memprediksi kinerja berdasarkan variabel bebasnya.

\section{Uji Linieritas Data}

Dari hasil olah data grafik Normal P-Plot of Regretion Standardized, terlihat titik-titik (data) di sekitar garis lurus dan cenderung membentuk garis lurus (linier), sehingga dapat dikatakan bahwa persyaratan linieritas telah terpenuhi. Dengan demikian karena persyaratan linieritas telah dapat dipenuhi sehingga model regresi layak dipakai untuk memprediksi kinerja berdasarkan variabel bebasnya.

\section{Uji Multikolinieritas Data}

Uji multikolinieritas perlu dilakukan untuk menguji apakah pada model regresi ditemukan adanya korelasi antar variabel bebas, jika terjadi korelasi, maka dinamakan terdapat problem Multikolinieritas. Untuk mengetahui multikolinieritas antar variabel bebas tersebut, dapat dilihat melalui VIF (variance inflation factor) dari masing-masing variabel bebas terhadap variabel terikat. Apabila nilai VIF tidak lebih dari 5 berarti mengindikasi bahwa dalam model tidak terdapat multikolinieritas.

Adapun hasil pengujian teringkas dalam tabel berikut :

\section{Tabel .3}

Hasil Uji Multikolinieriras Variabel Bebas

\begin{tabular}{|l|r|r|l|}
\hline \multicolumn{1}{|c|}{ Variabel bebas } & Tolerance & \multicolumn{1}{c|}{ VIF } & \multicolumn{1}{c|}{ Keputusan thp asumsi } \\
Tidak Multikolinieritas \\
\hline QWL & 0,808 & 1,238 & Terpenuhi \\
\hline Need for Achievement & 0,828 & 1,207 & Terpenuhi \\
\hline Need for Afiliation & 0,744 & 1,343 & Terpenuhi \\
\hline Need for Power & 0,819 & 1,221 & terpenuhi \\
\hline
\end{tabular}

Sumber: Data diolah

Pada tabel di atas terlihat bahwa keempat variabel bebas memiliki besaran angka VIF di bawah 5, sehingga asumsi tidak terjadi multikolinieritas terpenuhi dan model regresi layak digunakan. 


\section{Uji Autokorelasi}

Uji autokorelasi digunakan untuk mengetahui ada atau tidaknya penyimpangan asumsi klasik autokorelasi yaitu korelasi yang terjadi antara residual pada satu pengamatan dengan pengamatan lain pada model regresi. Prasyarat yang harus terpenuhi adalah tidak adanya autokorelasi dalam model regresi.

\section{Tabel .4}

Hasil Uji Autokorelasi

\begin{tabular}{|c|c|c|c|c|}
\hline Persamaan & F & Sig & Ajusted R square & Durbin-Watson \\
\hline$(1)$ & $(2)$ & $(3)$ & $(4)$ & $(5)$ \\
\hline Persamaan & 15,898 & 0,000 & 0,219 & 2,354 \\
\hline
\end{tabular}

Sumber: Data diolah

Dari hasil output di atas didapat nilai DW yang dihasilkan dari model regresi adalah 2,354 Sedangkan dari tabel DW dengan signifikansi 0,05 dan jumlah data $(n)=214$, serta $\mathrm{k}=4$ (k adalah jumlah variabel independen) diperoleh nilai dL sebesar 1,728 dan dU sebesar 1,809. Kriteria penolahan Ho adalah :

\begin{tabular}{lllccc} 
Tolak Ho & $\mathrm{dL}$ & $\mathrm{du}$ & terima Ho & 4-dL & Tolak Ho 4du \\
\hline 4 & 1,728 & 1,809 & 2,191 &
\end{tabular}

Nilai D = 2,299 terletak pada daerah penolakan Ho, sehingga asumsi tidak ada autokorelasi tidak dapat diterima. Dikarenakan ini penelitian data kualitatif maka hasil asumsi ini dapat diabaikan dan akan dilanjutkan ke pengolahan data berikutnya.

\section{Uji Heteroskedastisitas}

Uji heteroskedastisitas bertujuan menguji apakah dalam model regresi terjadi ketidaksamaan varian dari residual satu pengamatan ke pengamatan lain. Pendeteksian bisa dilakukan dengan menggunakan metode Glejser Test, yaitu dengan cara meregresikan nilai absolut residual terhadap variabel bebas.

Tabel .5.

Koefisien Regresi Variabel Bebas terhadap Residual

\begin{tabular}{|l|c|c|c|c|c|}
\hline \multicolumn{1}{|c|}{ Variabel } & Beta & $\mathrm{t}$ & Sig & F & Sig \\
\hline QWL & $(2)$ & $(3)$ & $(4)$ & $(5)$ & (6) \\
\hline Need for Achievement & 0,030 & 0,395 & 0,694 & 1,227 & 0,300 \\
\cline { 1 - 4 } Need for Afiliation & $-0,099$ & $-1,321$ & 0,188 & & \\
\cline { 1 - 4 } Need for Power & $-0,102$ & $-1,288$ & 0,199 & & \\
\cline { 1 - 4 } & $-0,006$ & $-0,086$ & 0,932 & & \\
\hline
\end{tabular}

Sumber: Data diolah 
Dari hasil keluaran SPSS tersebut menunjukkan bahwa nilai signifikansi lebih besar dari 0,05 sehingga disimpulkan bahwa terjadi heteroskedastisitas dalam model tersebut. Meskipun demikian, model regresi ini tetap dapat dilanjutkan dikarenakan merupakan data perilaku.

6. Pengujian F Regresi Berganda

Uji F digunakan untuk menguji secara bersama-sama (simultan) apakah semua variabel bebas bersama-sama mempunyai pengaruh yang signifikan terhadap variabel tidak bebasnya. Hasil uji simultan dapat dilihat pada tabel berikut.

Tabel .6.

Koefisien Regresi

\begin{tabular}{|l|c|c|c|c|c|c|}
\hline \multicolumn{1}{|c|}{ Variabel } & Beta & $\mathrm{t}$ & $\mathrm{Sig}$ & $\mathrm{F}$ & $\mathrm{Sig}$ & $\begin{array}{c}\text { Adjusted } \\
\mathrm{R}^{2}\end{array}$ \\
\cline { 1 - 5 }$(1)$ & $(2)$ & $(3)$ & $(4)$ & $(5)$ & $(6)$ & $(7)$ \\
\hline QWL & 0,134 & 1,994 & 0,047 & & & \\
\cline { 1 - 4 } Need for Achievement & 0,142 & 2,130 & 0,034 & \multirow{2}{*}{15,898} & 0,00 & 0,219 \\
\cline { 1 - 5 } Need for Afiliation & 0,332 & 4,723 & 0,000 & & & \\
\cline { 1 - 5 } Need for Power & 0,049 & 0,730 & 0,466 & & & \\
\hline
\end{tabular}

Sumber: Data diolah

Dari hasil pengolahan SPSS diperoleh F hitung sebesar 15,898, yang lebih besar daripada F tabel, maka Ho ditolak, yang artinya bahwa terdapat pengaruh positif signifkan QWL, Need for Achievement, Need for Afiliation, dan Need for Power terhadap Kinerja ( H.1).

Dengan koefisien determinan 0,219 atau 21,9\% Variabel kinerja mampu dijelaskan oleh QWL, Need for Achievment, Need for Afiliation, serta Need for Power. Jadi jika terjadi peningkatan Quality of Work Life maka kinerja akan meningkat, demikian juga dengan Need for Achievement, Need for Afiliation, dan Need for Power jika meningkat maka kinerja juga akan meningkat.

\section{Uji Parsial T}

a) Pada tabel D.7.1. kolom (3) baris QWL terlihat $t$ hitung sebesar 1,994 dengan tingkat signifikansi 0,047 dan berada di atas tingkat signifikansi yang disyaratkan 0,05, maka kesimpulan tolak Ho, artinya terdapat pengaruh positif signifikan antara QWL dengan kinerja.

b) Pada tabel D.7.1. kolom (3) baris Need of Achievement t hitung sebesar 2,130 dengan tingkat signifikansi 0,034 dan berada di atas tingkat signifikansi yang disyaratkan 0,05, maka kesimpulan tolak Ho, artinya terdapat pengaruh positif signifikan antara Need for Achievement dengan kinerja.

c) Dari tabel D.7.1. kolom (3) baris Need for Afiliation terlihat t hitung sebesar 4,723 dengan tingkat signifikansi 0,00 dan berada dibawah tingkat signifikansi yang disyaratkan 0,05, maka kesimpulan tolak Ho, artinya terdapat pengaruh positif signifikan antara Need for Afiliation dengan kinerja.

d) Dari tabel D.7.1. kolom (3) baris Need for Power terlihat t hitung sebesar 0,049 dengan tingkat signifikansi 0,466 dan berada di atas tingkat signifikansi yang disyaratkan 0,05, maka 
kesimpulan terima Ho, artinya tidak terdapat pengaruh positif signifikan antara Need for Power dengan kinerja.

Secara ringkas hasil pengujin hipotesis regresinya sebagai berikut:

Tabel .7.

Hasil Pengujian Hipotesis

\begin{tabular}{|c|l|l|}
\hline Hipotesis & \multicolumn{1}{|c|}{ Deskripsi } & Kesimpulan \\
\hline H.2 & QWL berpengaruh positif signifikan terhadap kinerja & Diterima \\
\hline H.3 & $\begin{array}{l}\text { Need for Achievement berpengaruh positif signifikan terhadap } \\
\text { kinerja }\end{array}$ & Diterima \\
\hline H.4 & $\begin{array}{l}\text { Need for Afiliation berpengaruh positif signifikan terhadap } \\
\text { kinerja }\end{array}$ & Diterima \\
\hline H.5 & Need for Power berpengaruh positif signifikan terhadap kinerja & Ditolak \\
\hline
\end{tabular}

\section{B. Pembahasan}

1. Pengujian terhadap hipotesis 1 dalam penelitian ini menyatakan bahwa terdapat hubungan positif signifikan antara Quality of Work Life terhadap kinerja Pegawai kecamatan di Kabupaten Kulon Progo. Hal ini menunjukkan bahwa apabila kondisi instrumen kualitas kehidupan kerja dari dimensi partisipasi, restrukturisasi kerja, sistem imbalan dan lingkungan kerja ditingkatkan maka kinerja Pegawai kecamatan di Kabupaten Kulon Progo akan meningkat.

2. Pengujian terhadap hipotesis 2 dalam penelitian ini menyatakan bahwa terdapat hubungan positif signifikan antara Need for Achievement terhadap kinerja Pegawai kecamatan di Kabupaten Kulon Progo. Hal ini menunjukkan bahwa motivasi akan kebutuhan berprestasi bagi pegawai kecamatan di Kabupaten Kulon Progo perlu diperhatian oleh pihak Satuan Kerja Perangkat Daerah mengingat variabel ini mempunyai signifikansi terhadap kinerja pegawai.

3. Pengujian terhadap hipotesis 3 dalam penelitian ini menyatakan bahwa terdapat hubungan positif signifikan antara Need for Afiliation terhadap kinerja Pegawai kecamatan di Kabupaten Kulon Progo. Hal ini berarti bahwa kebutuhan akan motivasi Need for Afiliation yang dimiliki oleh pegawai tersebut menunjukkan, apabila motivasi berafiliasi yang dimiliki oleh seorang pegawai semakin tinggi maka kinerja pegawai tersebut juga akan semakin tinggi. Hal ini berrmakna bahwa seorang pegawai yang memiliki hubungan sosial dan pertemanan yang tinggi akan berpengaruh terhadap kinerja yang dihasilkan oleh pegawai yang bersangkutan dan setiap upaya untuk meningkatkan dan mempertahankan hubungan terhadap masing-masing pegawai tersebut akan dapat meningkatkan kinerja Pegawai Kecamatan di Kabupaten kulon Progo. Hasil penelitian terhadap kebutuhan berafiliasi ini juga sesuai dengan teori yang dikemukakan McClelland bahwa motivasi berafiliasi erat hubungannya dengan kehidupan sosial seseorang. Kebutuhan akan afiliasi pada umumnya tercermin pada keinginan untuk berada pada situasi yang bersahabat dalam berinteraksi seseorang dengan orang lain dalam organisasi, karena dalam kondisi yang bersahabat dan kooperatif tersebut maka kinerja organisasi dapat ditingkatkan.

4. Pengujian terhadap hipotesis 4 menunjukkan hasil bahwa Need for Power tidak berpengaruh positif signifikan terhadap kinerja Pegawai Kecamatan di Kabupaten Kulon Progo. Hasil penelitian terhadap kebutuhan akan kekuasaan ini tidak sesuai dengan teori yang dikemukakan McClelland bahwa motivasi berkuasa sangat berhubungan dengan suatu keinginan untuk berpengaruh kepada orang lain sehingga memungkinkan sekali dari keinginan ini akan menimbulkan keunggulan terhadap orang lain dalam bekerja. 
5. Beberapa hal yang mempengaruhi, mengapa kebutuhan akan kekuasaan tidak signifikan terhadap kinerja Pegawai Kecamatan di Kabupaten Kulon Progo, di antaranya : umur dan masa kerja mendekati pensiun, selain itu masing-masing pegawai mempunyai kesadaran bekerja untuk melaksanakan pekerjaan sesuai unit kerja tugas pokok di unit kerjanya. Setiap pegawai sudah mempunyai tugas masing-masing dan akan diukur melalui penilaian kinerja. Sehingga keinginan kebutuhan kekuasaan yang di refleksikan dengan keinginan yang besar untuk menanamkan pengaruh, mengarahkan dan mengendalikan orang lain tidak berlaku.

\section{KESIMPULAN}

\section{A. Simpulan}

Penelitian ini bertujuan untuk memberikan tambahan bukti empiris pengaruh QWL, Need for Achievment, Need for Afiliation, serta Need for Power terhadap kinerja. Simpulan dalam penelitian ini adalah sebagai berikut:

1. Secara simultan Quality of Work Life dan Motivasi (Need for Achievement, Need for Affiliation dan Need for Power ) secara bersamaan berpengaruh positif signifikan terhadap kinerja pegawai kecamatan di Kabupaten Kulon Progo

\section{Secara parsial}

a) Quality of Work Life mempunyai pengaruh positif dan signifikan terhadap kinerja pegawai kecamatan di Kabupaten Kulon Progo

b) Need for Achievement mempunyai pengaruh positif dan signifikan terhadap kinerja pegawai kecamatan di Kabupaten Kulon Progo

c) Need for Affiliation mempunyai pengaruh positif dan signifikan terhadap kinerja pegawai kecamatan di Kabupaten Kulon Progo

d) Need for Power tidak berpengaruh positif dan signifikan terhadap kinerja pegawai kecamatan di Kabupaten Kulon Progo.

\section{B. Keterbatasan}

Penelitian ini memiliki keterbatasan, dimana penulis masih terbatas dalam mengasumsikan bahwa kinerja hanya dipengaruhi oleh faktor-faktor Quality of Work Life dan Motivasi (Need for Affiliation, Need for Achievement dan Need for Power). Untuk penelitian selanjutnya dapat menggunakan maupun menambah variabel-variabel lain yang dapat mempengaruhi kinerja selain Quality of Work Life dan Motivasi ( Need for Achievement, Need for Affiliation dan Need for Power ) untuk mendapatkan hasil penelitian yang lebih bermanfaat.

\section{C.Saran}

Untuk lebih meningkatkan kinerja pegawai kecamatan di Kabupaten Kulon Progo maka pihak pimpinan/ pemerintah daerah lebih fokus dalam memberikan perhatian lebih terhadap upayaupaya dengan menciptakan kondisi :

1. Quality of Work Life, dari sisi partisipasi, restrukturisasi, sisten imbalan dan lingkungan kerja yang kondusif

2. Need for Achievement, dan Need for Affiliation pada pegawai, dalam penelitian ini juga sangat perlu untuk diperhatikan dalam meningkatkan dan menumbuhkan kinerja pegawai. 
Dengan mengelola sumber daya manusia pegawai kecamatan di Kabupaten Kulon Progo yang tepat dengan meningkatkan Quality of Work Life dan Need for Achievement, dan Need for Affiliation kinerja pegawai akan meningkatkan secara signifikan.

\section{DAFTAR PUSTAKA}

As'ad, M., 1991, Kepemimpinan Efektif dalam Perusahaan, Suatu Pendekatan Psikologik, Edisi Kedua Liberty, Yogyakarta.

Bruce, E. M., RSM Lau, and Stephen K. J., 1999, “ A Longitudinal Study of Quality of Work Life and Business Performance”, Business Review, Vol. LVIII, No. 2, p.3-7.

Cascio, W. F., 1991, Applied Psychology in Personal Management, 4th Edition,Prentice Hall International Inc.

Cascio, W. F., 1989, Managing Human Resources : Productivity, QWL and Profits, Irwin McGraw Hill.

Elmuti, Dean., Yunus, K., 1997, “An Investigation into Effects of ISO 9000 on Participants' Attitudes and Job Performance”, Production and Inventory Management Journal, Second Quarter.

Gibson, I. D., 1998, Organisasi, Perilaku, Struktur, Proses. Terjemahan: Djarkasih, Jilid I, II. Erlangga , Jakarta.

Gomes, F. C., 2003, Manajemen Sumber Daya Manusia. Penerbit Andi, Yogyakarta.

Handoko, T.H., 1996, Manajemen Personalia dan Sumberdaya Manusia. Cetakan 10. BPFE. Yogyakarta.

Lewis, D., Kevin, B., Paul Krueger., Lynne, L., and Erin, T., 2001, "Extrinsic and Intrinsic Determinants of Quality of Work Life”, International Journal of health Care Quality Assurance Incorporating Leadership in Health Service, Vol. 14, p.9-15.

Luthans, F., 1998, Organizational Behaviour, 8th edition,McGraw Hill Meredith, JR., (1992), The Management of Operations, a Concepttual Emphasis, 4th Edition, Prentice Hall International Inc.

Nawawi, H. H., 2001, Manajemen Sumber Daya Manusia untuk Bisnis yang Kompetitif, Gadjah Mada University Press, Yogyakarta.

Pruijt, H., 2003, "Performance and Quality of Work Life”, Journal of Organizational Change Management, Vol. 13, p.389-400.

Republik Indonesia, 2004, Undang-Undang Nomor 32 Tahun 2004 tentang Pemerintah Daerah, Penerbit CV.Eko Jaya, Jakarta.

Rivai, V., 2004, Manajemen Sumber Daya Manusia Untuk Perusahaan. Dari Tekhnik ke Praktik, Edisi 1 PT. Raja Grafindo Persada. Jakarta.

Saraji, G. N., \& Dargahi, H., 2006, Study of Quality of Work Life (QWL). Iranian J Publ Health, Vol. 35, No. 4, pp.8-14.

Tjahjono, H. K, 2009, Manajemen Sumberdaya Manusia. Edisi 2.0. Cetakan 1. Visi Solusi Madani. Yogyakarta.

Tjahjono, H.K. 2015. Metode Penelitian Bisnis. VSM MM UMY

Veithzal, R., 2005, Performance Appraisal. PT Raya Grafindo Persada. Jakarta. 
William B. W., \& Keith, D., 1989, Human Resousces and Personnel Management 3rd Edition. New York : McGraw Hill. 